\title{
Rozwój zrównoważony jako otwarty system aktywności
}

\author{
Krystyna Najder-Stefaniak \\ Wydział Socjologii i Pedagogiki, Szkoła Główna Gospodarstwa Wiejskiego w Warszawie \\ ul. Nowoursynowska 166, 02-787 Warszawa \\ krystyna_najder_stefaniak@sggw.pl• ORCID 0000-0003-4777-4663
}

\section{Streszczenie}

Autor artykułu traktuje pojęcie zrównoważonego rozwoju jako projekt rozumienia rzeczywistości i magazyn wiedzy, który jest wypełniany treścią od momentu wprowadzenia pojęcia do dyskursu nauki.

Pokazuje, że metafora ekosystemu pomaga zaproponować główne tezy artykułu: 1) zrównoważony rozwój to system aktywności, który wzbogaca środowisko społeczne i przyrodnicze ludzi; 2) w zrozumieniu jego specyfiki pomaga metafora życia; 3) zrównoważony rozwój musi być otwartym, względnie izolowanym systemem.

Pojęcie życia, zrównoważonego rozwoju, twórczego trwania i transgresji są kluczem do przedstawionych rozważań.

\section{Słowa kluczowe}

życie, rozwój zrównoważony, twórcze trwanie, transgresja

\section{Wstęp}

Zrozumienia zjawisk, które zauważamy, szukamy zawsze w jakimś porządku rozumienia wyznaczanym przez ontologiczne i epistemologiczne założenia oraz metafory podpowiadające, jak myśleć o relacjach i zależnościach. Istotne znaczenie dla skutków naszej aktywności, której celem jest poznanie prawdy, mają pojęcia, jakimi się posługujemy. One także pozostają pod wpływem systemu rozumienia, w jakim się pojawiają. Pojęcie, jako projekt rozumienia rzeczywistości, nakreśla sposób myślenia, a jako magazyn wiedzy - umożliwia korzystanie z efektów wcześniej realizowanej aktywności poznawczej.

George Simmel zwrócił uwagę na to, że każda epoka charakteryzuje się jakimś centralnym pojęciem, „z którego biorą początek ruchy umysłowe i do którego jakby powracają" (Simmel 2007: 56). To centralne pojęcie pełni funkcję podobną do funkcji „metafory dominującej”, której w dialogach Platona poszukiwał Pierre Louis (Louis 1945: 14). Dzięki takiej dominującej metaforze nasze myślenie o rzeczywistości staje się uporządkowane i jednocześnie nie jest zamknięte w sztywnym schemacie rozumienia.

Nieprecyzyjność znaczenia, jakie proponuje metafora, docenia Paul Ricoeur. Jego zdaniem zaletą metafor jest to, że nie są one nigdy do końca przejrzyste, zaletą, bo implikuje to możliwość bogactwa skojarzeń ( $\mathrm{Ri}$ coeur 1975: 288, 373). Ricoeur zwraca uwagę na jeszcze jedną bardzo ważną możliwość oferowaną przez metaforę. Umetaforycznienie jest cenne także dlatego, że dzięki niemu język może przenosić wyobrażenia. Może je 
przenosić nie tylko ze świadomości do świadomości, z kultury do kultury, lecz także przekazywać w dziedzictwie, staje się „tradycją-transmisją" i sprawia, że może tworzyć się kultura (Ricoeur 1985, t. III, rozdz. 7). Nie do końca przejrzysta, implikująca wielość skojarzeń, transmitująca tradycję wyobrażeń, metafora pomaga narzucić myśleniu określony porządek i jednocześnie nie usztywnić go w schematach wypracowanych w ontologii i epistemologii. Właśnie taką metaforą jest pojęcie „ekosystem” przeniesione z obszaru teorii biologicznej w obszar ontologii, porządkuje myślenie o bycie, byciu i relacjach.

Arystoteles, który jako pierwszy uznał metaforę za najogólniejszą formę wszystkich figur słowa, pisał w Poetyce: „Metafora (metaphora) jest to przeniesienie (epiphora) nazwy (onomatos) jednej rzeczy na inną (allotriou): z rodzaju na gatunek (apo tou genous epi eidos), z gatunku na rodzaj (apo tuo eidous api to genos), z jednego gatunku na inny (apo tuo eidous epi eidos), lub też przeniesienie nazwy z jakiejś rzeczy na inną na zasadzie analogii (e kata to analogon)" (Arystoteles 1983, XXI). Rozważa się metaforę w ramach semantyki, albo jako pośrednie przedstawienie unaoczniające. W pierwszym przypadku fundamentem ontycznym metafory jest znaczenie, w drugim - jej ontologia jest ikoniczna. W ramach semantyki metafora postrzegana jest jako mechanizm przekształceń znaczeniowych. Operacje dokonywane są na znaczeniu, a metafora jest typem narzędzia, instrumentem, typem operatora językowego (Dąbska 1967). Transformacja języka powoduje fundamentalny skutek semantyczny w postaci ustanowienia figury znaczeniowej. Metafora, którą rozważamy w ramach ontologii obrazu, to figura łącząca myślenie obrazowe i myślenie pojęciowe.

W dyskursie naukowym niezbędne są zarówno metaforyczne pojęcia, jakie znajdujemy w metafizyce, fizyce, matematyce i innych naukach, metaforyczne wypowiedzi i metafory dominujące, narzucające porządek naszemu wyobrażeniu świata, a także naszemu myśleniu o tym świecie i relacjach między jego elementami i wymiarami. Metafory, narzucając porządek myśleniu i w rezultacie dyskursowi, którym to myślenie skutkuje, mają jeszcze bardziej fundamentalny wpływ na myślenie i dyskursy, niż metanarracje, o znaczeniu których pisał Jean Francois Lyotard w La condition postmodern (Lyotard 1997). Lyotard pokazał, że zarówno wiedza nienaukowa, jak i przeciwstawiana jej wiedza naukowa ulegają wpływowi metanarracji, która implikuje sposób interpretacji i kierunki poszukiwań, podejmowane zagadnienia oraz zasady zajmowania się nimi. Zauważmy, że metafory sięgają głębiej niż metanarracje porządkujące to, co myślimy. Metafory w specyficzny sposób porządkują to, jak myślimy. Sprawiają, że mogą powstawać i trwać żyjące systemy kultury, religii, filozofii i nauki, że nasza myśl nie jest skazana ani na usztywnienie w konkretnych strukturach, ani na zagubienie w przygodności spostrzeżeń. Metafora ekosystemu implikuje zastąpienie porządkującego myślenie o relacjach schematu podmiot $\rightarrow$ przedmiot schematem relacji ekosystemowej. Ten nowy schemat relacji pomaga zrozumieć specyfikę życia.

Helmuth Plessner pisał, że każdy czas ma swoje „zbawienne słowo”, które w sposób istotny wpływa na to, jak postrzegamy i rozumiemy rzeczywistość. Zauważał, że w wieku XVIII takim słowem było podkreślające to, co ponadczasowe - pojęcie rozumu, w wieku XIX akcentujące nieustanne stawanie się i wzrost - pojęcie rozwoju, a na przełomie XIX i XX w. stało się nim - pojęcie życia (Plessner 1975).

Myślenie pozostające pod wpływem metafory ekosystemu i ogniskowane przez pojęcie życia, które rozumiemy jako charakteryzujące się twórczym trwaniem, dzieje się w nowym systemie rozumienia. W tym systemie relacje rozumiemy nie w liniowym, jednokierunkowym schemacie podmiot $\rightarrow$ przedmiot lub w interakcyjnym schemacie podmiot $\leftrightarrow$ podmiot, ale w schemacie relacji ekosystemowej. Pomaga on przekroczyć liniowe postrzeganie zależności 
i zauważyć, że pojęcie rozwoju zrównoważonego w sposób istotny różni się od pojęcia rozwoju. W rezultacie rozwój zrównoważony nie może być osiągnięty przez modyfikację rozwoju. Potrzebna jest zmiana jakościowa dotycząca rozumienia celu i podstaw aktywności. Rozwoju zrównoważonego nie musimy rozumieć jako ograniczonego rozwoju. Paradygmat myślenia ekosystemowego pomaga zauważyć, że nie osiągniemy go, ograniczając aktywność, lub zamykając ją w takiej strukturze systemu aktywności, która uniemożliwia transgresję.

W nowym kontekście rozumienia rozwój zrównoważony możemy postrzegać jako otwarty system aktywności, który przyczynia się do wzbogacenia złożonego środowiska społeczno-przyrodniczego i do wzbogacenia człowieka. Planując i realizując rozwój zrównoważony, należy widzieć zależności w schemacie relacji ekosystemowej. Schemat relacji ekosystemowej pomaga sformułować trzy ważne tezy:

- rozwój zrównoważony jest systemem aktywności wzbogacającej społeczno-przyrodnicze środowisko człowieka;

- by mógł się realizować, musi być otwartym, względnie izolowanym systemem aktywności;

- $\quad$ zrozumieć specyfikę rozwoju zrównoważonego pomaga metafora życia.

Kluczowe dla zrozumienia specyfiki rozwoju zrównoważonego okazują się pojęcia: życie, twórcze trwanie i transgresja.

\section{2. Życie jako centralne pojęcie myślenia ekosystemowego}

Centralnym pojęciem, z którego w paradygmacie myślenia ekosystemowego „biorą początek ruchy umysłowe i do którego jakby powracają", jest określone pojęcie życia. Życie można postrzegać jako to, co demoniczne i w sposób nieświadomy twórcze, lub podkreślać, że jego specyfiką jest twórcze trwanie łączące trzy wymiary czasu: przeszłość, teraźniejszość i przyszłość. To drugie pojęcie życia jest pojęciem centralnym w paradygmacie myślenia ekosystemowego. Myślenie o zależnościach w schemacie relacji ekosystemowej pomaga zrozumieć, jak możliwe jest takie twórcze trwanie i transgresja ku przyszłości, którymi charakteryzują się systemy żywe.

Pojęcie transgresji używane bywa w różnych kontekstach ${ }^{1}$. We wszystkich rodzajach transgresji polega ona na poszerzaniu obszaru bycia. Jest przekraczaniem granic niezwiązanym z rezygnacją z tego, co było w dotychczasowych granicach. Transgresja może być ekspansywna i twórcza. Ekspansywna polega na poszerzaniu zasobów lub terytorium. Twórcza natomiast poszerza zakres możliwości związanych z aktywnością. Pośrednio wpływa na zmianę środowiska i przestrzeni, w której się dokonuje. Twórczej transgresji dokonują systemy żywe. Dokonując twórczej transgresji, wzmacniają własną podmiotowość i poszerzają granice możliwości własnego świata.

Helmuth Plessner, korzystając z odkryć naukowych biologów i interpretując je w duchu filozofii, zwrócił uwagę na podwójne usytuowanie bytu ożywionego, który jest jednocześnie „wewnątrz siebie” i „naprzeciw siebie" (Plessner 1975). Konsekwencją tego podwójnego usytuowania jest dwuaspektowy sposób przejawiania się bytów ożywionych. Badanie fenomenu życia wymaga wypracowania odpowiedniej metody, która będzie w stanie uwzględnić takie podwójne usytuowanie (Plessner 1975). Jeżeli myślenie o rozwoju zrównoważonym porządkuje metafora życia, to dostrzegamy dwuaspektowy sposób przejawiania się rozwoju zrównoważonego.

$1 \mathrm{~W}$ genetyce oznacza zjawisko silniejszego rozwoju pewnej cechy u potomstwa niż w organizmach rodzicielskich. W naukach o Ziemi transgresją nazywa się zajmowanie nowego obszaru przez morze, lodowiec, pustynię itp. wskutek ruchów tektonicznych lub zmian klimatycznych. W zaproponowanym przez Józefa Kozieleckiego psychotransgresjonizmie jest rozumiana jako zdolność przekraczania granic materialnych, społecznych i symbolicznych - zjawisko polegające na tym, że człowiek intencjonalnie wychodzi poza to, czym jest i co posiada. 
Plessner dostrzega też jeszcze inny problem metodologiczny związany z badaniem zjawiska życia. Jego zdaniem, nie może ono być badane w granicach jednej nauki. Zauważa on konieczność przekroczenia granic nauk szczegółowych i wyzwolenia się z ograniczeń wynikających z tego, że każda nauka, zarówno przyrodnicza, jak i humanistyczna, przeprowadza na swoim obiekcie szczególnego rodzaju redukcję, która znajduje odzwierciedlenie w jej pojęciach (Plessner 1975: 25). Ta redukcja utrudnia zrozumienie życia. Redukcję fenomenu życia zauważamy też w różnych sposobach myślenia o tym zjawisku. Wyróżniamy cztery paradygmaty myślenia o życiu:

- $\quad$ sprowadzanie fenomenu życia do poziomu mechanicystycznego, a następnie molekularnego,

- $\quad$ ujęcie fenomenu życia z perspektywy stanowiska witalistycznego,

- ujęcie fenomenu życia przez pryzmat myślenia systemowego,

- ujęcie fenomenu życia w paradygmacie myślenia ekosystemowego.

Jak trudne do zamknięcia w definicji jest życie, uświadamia jego poetycki opis: „Jest istnieniem tego, co właściwie nie może istnieć, co w słodkiej męce chwieje się tylko między bytem a niebytem podczas zawikłanego i gorączkowego procesu rozpadu i wiecznego stawania się. Nie jest materialne i nie jest z ducha. Jest czymś pośrednim, jest zjawiskiem uwarunkowanym przez materię, niby tęcza na wodospadzie, niby płomień." (Mann 1998: 406). Poszukiwaniem istoty życia zajmują się przede wszystkim filozofowie. Biolodzy interesują się systemami, które uznano za żywe. Prowadzą badania dotyczące przejawów i specyfiki życia. Zauważają, że żywe organizmy charakteryzują się zdolnością do pobierania energii i materii z zewnątrz, zdolnością do rozrodu i koniecznością umierania. Złożoność życia, jego otwartość i wieloaspektowość najłatwiej zrozumieć w paradygmacie myślenia ekosystemowego.

Pojęcia ekosystemu po raz pierwszy użył A.G. Tansley w rozprawie The Use and Abuse of Vegetational Concepts and Terms, nazywając tak system wzajemnych oddziaływań (Tansley 1935: 299). Na specyfikę tych oddziaływań zwraca uwagę etymologia słowa „ekosystem”, która każe łączyć wyobrażenie domu z pojęciem systemu. Dom oznacza nasze miejsce pobytu, miejsce, które jest schronieniem i pomaga nam stawać się sobą, miejsce, które jest naszym środowiskiem i którego częścią my jesteśmy. System jest pojęciem projektującym rozumienie relacji w stanowiącym całość układzie. W XX w. stał się ważnym pojęciem w refleksji filozoficznej za sprawą uważanego za twórcę nowożytnej teorii systemów Ludwiga von Bertalanffy'ego, który zaproponował teorię systemów pozwalającą wyjaśnić strukturę żywego organizmu (von Bertalanffy, 1984). W teorii tej potrzebny okazał się wprowadzony przez twórcę nowoczesnej teorii systemów termin ekwifinalność oznaczający podstawową właściwość każdego systemu otwartego, wyrażającą się w tym, że odmiennie niż w układach nieożywionych, stan końcowy układu bywa osiągany różnymi drogami przy różnych warunkach początkowych. Bertalanffy twierdził, że różne systemy (fizyczne, biologiczne, psychologiczne, społeczne) mają wspólne zasady funkcjonowania. Tym twierdzeniem inspiruje do porównań zasad funkcjonowania systemów biologicznych i systemu aktywności, jakim jest rozwój zrównoważony.

Fizyk i filozof argentyński, prof. uniwersytetu w Buenos Aires, urodzony 18 lat później niż Bertalanffy, Mario Bunge zauważył, że dla zrozumienia działania i zmian stanów systemu niezbędne jest pojęcie otoczenia (Bunge 1979). Logik i filozof Józef Maria Bocheński twierdził, że każdy system ma co najmniej dwa elementy, które należą do tego samego typu logicznego co on i zasadę syntetyczną. W systemie elementy są od siebie zależne przyczynowo. Te zależności są inne w systemach scentralizowanych, gdzie wszystkie elementy zależą od jednego elementu centralnego, i inne w systemach niescentralizowanych, gdzie nie ma takiego wyróżnionego elementu i wszystkie 
elementy zależą od siebie nawzajem. Ze względu na relację z otoczeniem systemy są otwarte (np. żywa komórka) lub zamknięte (np. system aksjomatyczny) (Bocheński 1994: 239-246).

Ekosystem nie jest scentralizowany i jest otwarty. Zależności obrazuje tu schemat relacji ekosystemowej. Edgar Morin zwrócił uwagę na myśl, jaką znalazł u jednego z pionierów rewolucji biologicznej, Erwina Schrodingera, myśl, że ekosystem współorganizuje i bierze udział w programowaniu należących doń organizmów (Morin 1977: 46). Morin, akcentując teoretyczne konsekwencje takiego założenia jako niezwykle doniosłe, pisze: „relacja ekosystemowa to nie zewnętrzny stosunek dwóch zamkniętych bytów; chodzi tu o stosunek interakcyjny, zachodzący między dwoma układami otwartymi, z których każdy, będąc całością, stanowi zarazem część tej drugiej całości" (Morin 1977: 46).

Zrozumieć specyfikę żywych systemów pomaga wprowadzone przez Romana Ingardena pojęcie „systemów względnie izolowanych" (Ingarden 1972). Filozof wprowadził je w kontekst refleksji związanej z poszukiwaniem ontycznych podstaw odpowiedzialności. Ingarden zauważył, że warunkiem podstawowym bycia podmiotem odpowiedzialności jest posiadanie „w sobie centrum działania, które umożliwia [...] uchwycenie inicjatywy" (Ingarden 1972: 133). Osoba będąca podmiotem odpowiedzialności musi też „mieć w swej budowie urządzenia obronne, aby nie przeszkadzano jej w działaniu" (Ingarden 1972: 133). Jednocześnie musi być otwarta na otoczenie. Jak twierdził Ingarden, osoba odpowiedzialna „W swoich właściwościach i postępowaniu musi być tedy «otwarta» i podatna, a zarazem pod innym względem chroniona i niewrażliwa" (Ingarden 1972: 133). Zdaniem Ingardena, „działająca osoba (pewna całość stanowiąca jedność wraz z ciałem) musi tworzyć system względnie izolowany, i to system całkiem szczególnego rodzaju, który nie jest możliwy u rzeczy martwych, a który także nie u wszystkich istot żywych może się zrealizować" (Ingarden 1972: 134). Zdaniem autora, za pojęcia „system względnie izolowany" odpowiedzialne mogą być tylko istoty żywe, ponieważ tylko one mają źródło aktywności w sobie i jednocześnie kontaktują się z otoczeniem. Korzystając z odkrycia Bertalanffy'ego, że wszystkie systemy aktywności mają wspólne zasady funkcjonowania, możemy zapytać, czy ekosystem jest systemem względnie izolowanym, ma źródło aktywności w sobie i w rezultacie jest odpowiedzialny w sensie etycznym, czyli jest sprawcą skutków swojej aktywności? Pojęcie systemów względnie izolowanych pomaga myśleć o specyfice żywych systemów, jakimi są ekosystemy. Zauważyć, że mają one wymiar podmiotowości i zapytać, czy i jakie prawa oraz ograniczenia powinny im przysługiwać w związku z tym. Pomaga też zrozumieć specyfikę rozwoju zrównoważonego, jako otwartego wciąż wzbogacającego się systemu aktywności, który skutkuje wzbogaceniem złożonego środowiska społeczno-przyrodniczego a także wzbogacenia człowieka.

W ekosystemie mamy wyjątkową możliwość zrealizowania potencjalności zaistnienia zarówno systemu, jak i jego elementów dzięki specyfice relacji ekosystemowej, zachodzącej między dwoma układami otwartymi, z których każdy, będąc całością, stanowi zarazem część tej drugiej całości. „Ekosystem” przeniesiony z obszaru biologii w obszar rozważań metafizycznych, staje się jakby rodzajem modelu, który pełni funkcję inspirującą i sugeruje możliwości interpretacyjne $\mathrm{w}$ odniesieniu do podejmowanych przez metafizyków zagadnień, a w konsekwencji zaczyna porządkować całe myślenie w paradygmacie nauki. W tym modelu ważną cechą wszystkich żyjących systemów jest to, że podobnie jak systemy przyrodnicze, zarówno one same, jak i ich elementy nie mogą istnieć samodzielnie. W swoim artykule Kazimierz Dobrowolski pisał: „układy mniej skomplikowane (niższe), w zasadzie nie mogą istnieć samodzielnie, bez istnienia układu następnego, który tworzą. I tak komórka, w zasadzie nie istnieje poza tkanką, 
tkanka poza narządem, narząd poza organizmem, organizm poza populacją, populacja poza biocenozą bądź ekosystemem, a ten ostatni - poza krajobrazem ekologicznym" (Dobrowolski 1997: 6). Zauważał też, że każdy z funkcjonalnych układów biologicznych ma swoiste cechy i właściwości, „których nie sposób wyjaśnić i do końca poznać przez proste zsumowanie wiedzy o cechach i właściwościach poziomu poprzedniego (niższego)" (Dobrowolski 1997: 6). Inną ważną cechą systemów współtworzonych przez żywe organizmy jest to, że dążą one do własnej równowagi dynamicznej, czyli jakby same się porządkują. Łączą się w większe układy funkcjonalne, które istnieją na podobnej zasadzie.

W kontekście tej obserwacji przydatne okazuje się pojęcie informacji biologicznej. Nazwano tak „każdy rodzaj oddziaływania (zarówno wewnętrznego, jak i zewnętrznego) na organizm (i wewnątrz niego), przebiegający na każdym poziomie organizacyjnym, służący organizmowi do życia i przeżycia w warunkach aktualnych i przyszłych" (Latawiec 1996: 231-239). Żywy system wymaga do swego istnienia wymiany materii, energii i informacji. Materia i energia zasilają system, a informacja steruje zasilaniem.

Informację biologiczną podzielono na dwa rodzaje: informację zewnętrzną i wewnętrzną (Latawiec 1983). Kryterium tego podziału jest lokalizacja źródła informacji w relacji do organizmu. Daną informację wewnętrzną zaliczamy do właściwego typu w zależności od tego, na jakim poziomie organizacji pojawia się i wyzwala zaistnienie określonego stanu: „Na poziomie molekularnym pojawia się informacja genetyczna i immunologiczna, na poziomie komórkowym i tkankowym - informacja strukturalna itd. Informacja genetyczna, zawarta w kwasach nukleinowych i utrwalana w odtwarzalnych strukturach wielkocząsteczkowych, zapisana w kodzie genetycznym niesie informację o rodzaju i czasie syntetyzowania określonych białek. Jest obecna w najprostszych organizmach żywych. Jej brak powoduje proces syntezy białka, a w konsekwencji ustanie wszelkich procesów życiowych. Na poziomie molekularnym pojawia się także informacja immunologiczna niesiona za pośrednictwem antygenów i przeciwciał $\mathrm{w}$ reakcjach serologicznych. Jest tym typem informacji, który obecny jest tylko w niektórych żywych istotach. Należy więc uznać, iż nie jest informacją niezbędną. Jednakże tam, gdzie organizm jest przystosowany do jej odbioru, tam jest niezbędna. Oznacza to, że przystosowanie do odbioru informacji immunologicznej jest równoznaczne z brakiem innych zabezpieczeń, „systemów alarmowych” ostrzegających przed zagrożeniem prowadzącym do wyniszczenia lub zniszczenia organizmu. Na poziomie komórkowym pojawia się informacja strukturalna, która związana jest z budową i odbudową niszczonych fragmentów ciała roślin i zwierząt." (Latawiec 1983). Jeżeli zestawimy wprowadzone przez Romana Ingardena pojęcie systemu względnie izolowanego z pojęciem informacji, to możemy wyjaśnić względną niezależność takiego systemu. Posiadając swoją wewnętrzną informację, system „po swojemu” reaguje na komunikaty zewnętrzne. Anna Latawiec, badając koncepcję informacji biologicznej, dochodzi do wniosku, że o życiu nie można mówić w oderwaniu od informacji (Latawiec 1983). Warunkiem zaistnienia i istnienia życia jest obecność informacji (Latawiec 1983: 151). Harmonijny przebieg procesów i zachowanie dynamicznej równowagi dokonuje się w oparciu o informacje zewnętrzne i wewnętrzne, które w układzie żywym podlegają przetworzeniu (Ślaga 1982: 335).

Ekosystemowy model funkcjonowania implikuje powrót do czterech przyczyn Arystotelesa. Dla zrozumienia ekosystemu ważna jest zarówno przyczyna sprawcza, materialna, formalna i celowa. Ekosystem to holistycznie postrzegany otwarty układ funkcjonalny, przez swe dążenie do własnej równowagi dynamicznej podobny do układu względnie izolowanego, układ, którego elementy współtworzą go i są współtworzone przez niego, a w konsekwencji współtworzą 
siebie nawzajem. Układ ten zachowuje własności swoich elementów, tzn. nie może istnieć w izolacji, jest elementem układu szerszego, który współtworzy i przez który jest współtworzony.

W układach funkcjonalnych, jakim jest ekosystem, konstytuujące są relacje. To dzięki specyfice relacji ekosystemowych systemy mogą twórczo trwać. Dzięki zależnościom wynikającym z tych systemów może istnieć życie i może realizować się rozwój zrównoważony. Postrzeganie relacji w ekosystemie staje się punktem wyjścia do konstytuowania się nowego paradygmatu myślenia. Znaczenie nowego rozumienia relacji dla kształtowania się współczesnego postrzegania i interpretowania rzeczywistości podkreśla Edgar Morin, współczesny francuski historyk i socjolog, zajmujący się powstawaniem złożoności. Nowe postrzeganie relacji pozwala zrozumieć zarówno złożoność życia, jak i specyfikę rozwoju zrównoważonego.

\section{Specyfika rozwoju zrównoważonego}

Pojęcie rozwoju zrównoważonego jest dziś ważne nie tylko w dyskursie ekologicznym, lecz także jest wieloznaczne. Ma ono swoje korzenie w idei zrównoważonej gospodarki leśnej, wprowadzonej w 1713 r. przez Hansa Carla von Carlowitza (1645-1714) w jego książce Sylvicultura Oeconomica, oder haußwirthliche internetowa und $\mathrm{Na}$ turmäßige Anweisung zur Wilden Baum-Zucht, uznanej za pierwszy kompleksowy traktat o leśnictwie. Pojawiło się w kontekście problemów przemysłu wydobywczego potrzebującego bardzo dużych ilości drewna. Wypełniane jest treścią proponowaną pod wpływem promieniowania kontekstów, w jakich jest używane. Dziś może konkurować z ogniskującym myślenie w kulturze europejskiej od XX w. pojęciem życia rozumianego jako demoniczne i w sposób nieświadomy twórcze. Może też współbrzmieć z pojęciem życia, jakie pojawiło się w XXI w., życia rozumianego jako twórcze trwanie łączące przeszłość, teraźniejszość i przyszłość.
Hans Carl von Carlowitz wprowadził pojęcie „zrównoważenie” (niem. Nachhaltigkeit), nazywając nim taki rodzaj gospodarki leśnej, która powoduje, że las może się regenerować i ma szansę nie zostać zlikwidowany w trakcie eksploatacji. Uznanie, jakim cieszyła się niemiecka gospodarka leśna na początku XIX w., spowodowało, że pojęcie „zrównoważenie" zostało przejęte przez naukowców z innych krajów. W latach osiemdziesiątych XX w. określenie „sustainable” przejęli działacze ruchów ekologicznych i zaczęło ono funkcjonować w kontekście szerszym niż gospodarowanie lasem. W roku 1975 pojawiło się pojęcie rozwoju zrównoważonego, które może budzić wątpliwości jako łączące dwa przeciwstawne pojęcia: rozwój i zrównoważenie.

W roku 1972 rezolucją Zgromadzenia Ogólnego ONZ została powołana agenda UNEP (United Nations Environment Programme) w celu prowadzenia działań w zakresie ochrony środowiska i stałego monitorowania jego stanu na świecie. W pracach prowadzonych w związku z realizowaniem tego celu ważne okazało się pojęcie „sustainable development”. Rada Zarządzająca UNEP zaproponowała definicję tego pojęcia. W zaproponowanej definicji sustainable development jest wtedy, gdy przebieg nieuchronnego rozwoju gospodarczego nie narusza w sposób istotny i nieodwracalny środowiska życia człowieka, nie doprowadza do degradacji biosfery.

Projektując i realizując tak zdefiniowany sustainable development, uwzględniamy i staramy się godzić prawa przyrody, ekonomiki i kultury. Autorzy zaproponowanej definicji zakładają nieuchronność rozwoju gospodarczego i dostrzegają problem zagrożeń wynikających z tego rozwoju. Wiedzą, że może on być osiągany kosztem zniszczeń w obszarze kultury i przyrody, a pośrednio kosztem człowieka, który nie może w pełni się realizować w zdegradowanym środowisku społeczno-przyrodniczym. Rozwój kojarzy się z możliwością zachwiania równowagi funkcjonowania systemu, jakim jest to środowisko. Nowy, konstytuujący się 
współcześnie paradygmat myślenia porządkowanego przez metaforę ugruntowaną w pojęciu ekosytemu pomaga odkryć w połączeniu pojęć „rozwój” i „zrównoważony” nowe aspekty zarówno rozwoju, jak i równowagi. Pomaga też zrozumieć znaczenie kontekstu, w którym pojawia się pojęcie.

Dzięki Immanuelowi Kantowi zauważamy, że język nie jest tworem wtórnym względem rzeczywistości, nie powiela jej, nie proponuje pojęć, które są jej symbolicznym odpowiednikiem, lecz porządkuje nasze myślenie i nasze rozumienie rzeczywistości. Pojęcia, którymi się posługujemy, sugerują wnioski i decyzje i w konsekwencji mają wpływ na nasze działania, a poprzez nie na kształt człowieczego świata. Pojęcie rozwoju zrównoważonego występuje w różnych kontekstach i w rezultacie znajdujemy różne jego definicje. Porównajmy dwa przykłady definicji rozwoju zrównoważonego.

Jedna z nich zaproponowana została w 1987 r., w raporcie Organizacji Narodów Zjednoczonych noszącym tytuł Nasza Wspólna Przyszłość (Raport Brundtland). Jej autorzy twierdzą, że rozwój zrównoważony jest to rozwój, który zapewnia zaspokojenie potrzeb obecnych pokoleń, nie przekreślając możliwości zaspokojenia potrzeb pokoleń następnych. Z tej definicji możemy wyciągnąć wniosek, że należy ograniczać zaspokajanie potrzeb obecnych pokoleń i że jesteśmy w stanie przewidzieć potrzeby przyszłych pokoleń tak, by uwzględniając te potrzeby, właściwie wpłynąć na przyszłe otoczenie człowieka. Taki wniosek pojawia się w kontekście myślenia o rzeczywistości, które nie przypisuje jej cech życia, nie bierze pod uwagę tego, że ona twórczo trwa i dokonuje transgresji we wszystkich swoich wymiarach. Mogą więc też pojawić się nieprzewidywalne przez nas dziś potrzeby.

Inny wniosek sugeruje ta definicja, gdy korzystamy z paradygmatu myślenia ekosystemowego i w konsekwencji relacje, także te między teraźniejszością i przyszłością, rozumiemy w schemacie relacji ekosystemowej. Wtedy zauważamy, że warunek zaspokojenia potrzeb obecnych pokoleń i nieprzekreślania możliwości zaspokojenia potrzeb pokoleń następnych może być spełniony, gdy rozwój dzieje się w otwartym systemie aktywności. Rozwój zrównoważony powinien więc być otwartym systemem aktywności.

W 1992 r., w przeddzień Szczytu Ziemi w Rio de Janeiro, zaproponowana została przez polskie ruchy ekologiczne w opublikowanym raporcie Ekorozwój w Polsce kolejna definicja: „Zrównoważony rozwój, zwany także ekorozwojem, [...] jest tam, gdzie ludzie przewidują ograniczenia związane ze skończonością Planety i niezależnym od człowieka rytmem przyrody [...]. Jest to strategia osiągania godnego życia w ramach tego, co jest fizycznie i biologicznie możliwe. Gwarantuje ona zaspokajanie podstawowych potrzeb obecnego i przyszłych pokoleń, zachowując jednocześnie trwałość funkcjonowania środowiska przyrodniczego oraz naturalną różnorodność, zarówno gatunków, jak i ekosystemów.. W tej definicji akcent został położony na ograniczenia środowiska przyrodniczego, na skończoność fizycznych i biologicznych możliwości, na niewspółmierność rytmu przyrody i planowanych w liniowym schemacie zależności strategii działań. Skończoność i ograniczoność środowiska przyrodniczego, a także społeczno-przyrodniczego można skonfrontować z rozwojem zrównoważonym, który jest względnie izolowanym, otwartym systemem. Może on okazać się mądrą strategią na zwiększanie możliwości człowieka w zakresie twórczego przekraczania teraźniejszości.

\section{Podsumowanie}

Gdy porządek naszemu myśleniu narzuca metafora ekosystemu i gdy ogniskowane jest ono przez pojęcie życia, które rozumiemy jako charakteryzujące się twórczym trwaniem, łączącym wymiar teraźniejszości, przeszłości i przyszłości, zauważamy, że pojęcie rozwoju zrównoważonego w sposób istotny różni się od pojęcia rozwoju. Nie jest procesem lecz systemem bycia. By mógł się zrealizować, musi być otwartym, względnie izolowanym systemem bycia. 
Między rozwojem i rozwojem zrównoważonym jest różnica jakościowa, a nie ilościowa. Nie osiągniemy rozwoju zrównoważonego, tylko ograniczając rozwój, który akcentuje zmienność i wzrost. Rozwój zrównoważony nie może być liniowy. Nie może być ograniczony, okrojony, zamknięty w strukturze systemu bez możliwości transgresji. Jest otwartym, żywym system aktywności. Dzieje się w otoczeniu i odpowiada na możliwości i zagrożenia, jakich ono dostarcza, ale źródło aktywności ma w sobie. By się realizować, potrzebuje wymiany materii, energii i informacji. Materia i energia zasilają system, jaki stanowi, a informacja steruje zasilaniem. Jakość rozwoju zrównoważonego zależy od informacji.

\section{Bibliografia}

Arystoteles, 1983, Poetyka, XXI, tłum. H. Podbielski, Wydawnictwo Ossolineum, Warszawa.

Berman C., 1986, Ontologia „świata systemów” Mario Bungego, w: Projektowanie i systemy. Zagadnienia metodologiczne nauk praktycznych, t. 8, red. W. Gasparski i D. Miller, Wrocław.

Bocheński J.M., 1994, O systemie, „Principia”, VIII-IX, 1994.

Bunge M., 1979, Treatise on Basic Philosophy, vol. 3, Ontology I: The Furniture of the World, Dordrecht 1977; vol. 4, Ontology II: A World of Systems, Dordrecht.

Dąbska I., 1967, Z teorii instrumentalnego poznania, w: O narzędziach i przedmiotach poznania, Warszawa.

Dobrowolski K.A., 1997, Polskie nauki ekologiczne wobec wyzwań globalnych $i$ zadań praktycznych w kraju, w: Ziemia domem człowieka, red. J.L. Krakowiak, t. 2, Biblioteka Dialogu, Warszawa, 5-15.

Ingarden R., 1972, O odpowiedzialności i jej podstawach ontycznych, tłum. A. Węgrzecki, w: tenże: Książeczka o człowieku, WL, Kraków.
Latawiec A., 1983, Koncepcje informacji biologicznej, w: Z zagadnień filozofii przyrodoznawstwa i filozofii przyrody, t. 5, Warszawa, 151-259.

Latawiec A., 1996, Życie a informacja biologiczna, Śląskie Studia Historyczno-Teologiczne, 29, 231-239.

Louis P., 1945, Les métaphores de Platon, Les Belles Lettres, Rennes.

Mann T., 1998, Czarodziejska góra, tłum. J. Kram Sztyk, t. 1, Czytelnik, Warszawa.

Morin E., 1977, Zaginiony paradygmat - natura ludzka, tłum. R. Zimand, Państwowy Instytut Wydawniczy, Warszawa.

Najder-Stefaniak K., 2007, Metafora $w$ dyskursie filozoficznym, w: Piękno jako moment twórczości w ujęciu myślenia ekologicznego, Wydawnictwo SGGW, 11-20.

Najder-Stefaniak K., 2007, Implikacje metafory ugruntowanej w pojęciu ekosystemu, w: Piękno jako moment twórczości w ujęciu myślenia ekologicznego, Wydawnictwo SGGW, 21-35.

Najder-Stefaniak K., 2017, Transgresja $i$ wartości, w: Transgresja jako zjawisko w kulturze: $w$ kręgu szans i zagrożeń, red. A. Ciążela, S. Jaronowska, Wydawnictwo Akademii Pedagogiki Specjalnej, Warszawa, 37-46.

Plessner H., 1975, Die Stufen des Organischen. Einleiturg In die philosophische Antropologie, Walter de Gruyter, Berlin - NewYork.

Ricoeur P., 1975, La métaphore vice, Paris.

Ricoeur P., 1985, Temps et récit, t. 3, rozdz. 7, Paris. Heller M., Lubański M., Ślaga S.W. (red.), 1982, Zagadnienia filozoficzne wspótczesnej nauki, Wstęp do filozofii przyrody, Warszawa.

Tansley A.G., 1935, The Use and Abuse of Vegetational Concepts and Terms, Ecology, vol. 16.

Stróżewski W., 2004, Przedmiot jako system, w: Ontologia, Wydawnictwo Aureus, Znak, Kraków. 


\section{Sustainable development as open system of activity}

\section{Abstract}

The author of the paper treats the notion of sustainable development as a project of understanding the reality and storage of knowledge that has been filling with content since the moment it was introduced into the discourse of science. She shows that the ecosystem metaphor helps to propose the main theses of the speech: (1) sustainable development is a system of activity that enriches the social and natural environment of people; (2) to understand its specifics supports the metaphor of life; (3) sustainable development must be an open, relatively isolated system. The notions of life, sustainable development, creative persistence and transgression are the keys to the presented considerations.

\section{Keywords}

life, sustainable development, creative persistence, transgression 